\title{
The Truth about Vitamin C Enriched Plants and Vegetables Used in Nigeria for the Management of COVID-19 Uchejeso M Obeta $^{1^{*}}$, Goodluck AK Ohanube ${ }^{2}$ and Muhammad Akram ${ }^{3}$
}

\section{Affiliation:}

${ }^{1}$ Department of Medical Laboratory Management, Federal School of Medical Laboratory Science, Jos-Nigeria

${ }^{2}$ Department of Biomedical Sciences, University of Applied Sciences, Bonn-Rhein-Sieg, Germany

${ }^{3}$ Department of Eastern Medicine, Government College University Faisalabad-Pakistan

*Corresponding author: Uchejeso M Obeta, Department of Medical Laboratory Management, Federal School of Medical Laboratory

Science, Nigeria, Email: uchejesoobeta@gmail.com

Citation: Obeta MU, Ohanube GAK and Akram M. The truth about vitamin c enriched plants and vegetables used in Nigeria for the management of covid-19 (2021) Edelweiss Food Sci Tech 2: 7-9.

Received: Aug 02, 2021

Accepted: Sep 22, 2021

Published: Sep 28, 2021

Copyright: $\odot 2021$ Obeta MU, et al., This is an open-access article distributed under the terms of the Creative Commons Attribution License, which permits unrestricted use, distribution, and reproduction in any medium, provided the original author and source are credited.

\begin{abstract}
The COVID-19 pandemic has shown the dexterity and wits of Nigerians in the face of dire challenges. The low fatality recorded by Nigeria during the ongoing COVID-19 pandemic attests to this. A minimal death rate bewilders experts, despite the speculation that Nigeria might experience a high death rate, Nigerians resorted to home remedies for prophylaxis and curative measures using available vitamin $\mathrm{C}$ enriched plants and vegetables. This brief review explored various plants and vegetables reported to have been utilized during the COVID-19 pandemic in Nigeria. The obvious is that many Nigerians use one or more plants and vegetables as a home remedy. This spurred the interest of Nigerian scientists in more researches in Nigeria with the aim of standardization and registration for use.
\end{abstract}

Keywords: Plants, Vegetables, Vitamin C enriched, Covid-19 and Vitamins.

Abbreviations: SARS-COV-2- Severe Acute Respiratory Syndrome Coronavirus 2, WHO-World Health Organization, CDC-Centers for Disease Control and Prevention.

\section{Introduction}

Nigeria had her index case of COVID-19 on February 27, 2020. As at July 26, 2021 Nigeria has recorded 171,111 cases as number 86 across the globe with $1.25 \%$ fatality [1]. The COVID-19 pandemic stimulated research interest towards vitamin $\mathrm{C}$, vitamin $\mathrm{C}$ enriched plants and vegetables, herbs and conventional drugs towards adequate management of a new virus (SARS-COV-2). Notably are the recommendations of Calder, et al. [2] on the increased dose of Vitamin C in viral infections especially during COVID-19 and the emphatic postulation of Ohanube and Obeta (2020) [3] on the exact doses of vitamin $\mathrm{C}$ to use for prophylaxis and curative regimen in COVID-19 cases. In consideration that up to the time of writing this manuscript, there is no conventional or alternative medicine approved by WHO as a cure for COVID-19.

Many people in Nigeria resorted to home remedies, vitamin C enriched plants and vegetables, vitamin $\mathrm{C}$ in higher doses. Such approach depends on the countries, the people and the plants and vegetables available to provide the expected outcome. Basically the nutrients, both macro and micronutrients provides enormous immunity boosters in the body [4]. Such immune boosters are majorly found in vitamin $\mathrm{C}$ enriched plants and vegetables. Such brings into the picture the herbal theory [5] mostly used as home remedies for COVID-19. WHO [6] and CDC [7] having recognized herbal or traditional medicine is much interested in the preparation, standardization and incorporation in the healthcare $[8,9]$. Nigeria, popularly known as the giant of Africa, is blessed with plants and vegetables used in making herbs and traditional medicines.
Herbs have been in use for a long time for the purpose of treating and managing diseases and ailments including the ones that appear difficult to manage $[10,11]$. Due to the absence of a definitive cure for COVID-19, Nigerians resorted to plants and vegetables rich in vitamin $\mathrm{C}$.

\section{Methodology}

A brief review of online articles were carried out on some vitamin C enriched plants and vegetables that have been used in Nigeria either as home remedies or curative measures for COVID-19 in Nigeria.

\section{Discussion}

Some studies have enumerated some possible plants and vegetables that aid the management of COVID-19 [12-15]. Such plants and vegetables are seen in various case reports and reviews carried out in Nigeria. Obeta, et al. [14] identified bitter kola, garlic; giloy, ginger, lime, and turmeric in Igbo land (southeastern Nigeria). However, Oladele, et al. [16] in their excellent review identified several antimalarial, antiviral and antioxidants that are helpful in the management of COVID-19. Onyeaghala, et al. [17] in recent times, formulated a tea called Combi 5 following his case report of vitamin $\mathrm{C}$ enriched tea, which contains such vitamin $\mathrm{C}$ enriched plants including Ginger, Tumeric, black pepper, Garlic, and Negro pepper [17,18]. Obeta, et al. [19] in their case studies have used dry and fresh enriched vitamin $\mathrm{C}$ plants and vegetable to include bitter kola, cinnamon, garlic, ginger, turmeric and honey [20,21]. 
A careful follow-up of this study revealed the "locally prepared fruit juice" composed of blended orange, pawpaw, tomatoes, avocado, pineapple, cocoanut, banana, water melon, cucumba, carrot and apple. Also the soup taken with the pounded yam was composed of okro, pumpkin leaves, water leaf, Miango or Nsukka peppers. This case study showed enormous vitamin $\mathrm{C}$ content of the diet and medication. The case reports show true picture of adequate use of Vitamin C enriched plants and vegetables in Nigeria. WHO [9] supports the use of herbal mixtures in complementary medicine, but there may be a need for standardization before using them either for prophylaxis or cure. Hence, it is safe to say that the herbal mixtures which have shown the potential of boosting immunity could help manage COVID-19. This gives a cue for the approval of plants listed in Table 1 by various national agencies.

\section{Conclusion}

The fight against COVID-19 in Nigeria adopts many means such as the use of vitamin $\mathrm{C}$ enriched plants and vegetables and synthetic vitamin $\mathrm{C}$, wearing masks and other personal protective equipment, keeping a physical distance, and personal hygiene. It is important to note that daily use of most of the vitamin $\mathrm{C}$ enriched plants and vegetables enlisted in table 1 can provide prophylaxis for COVID19 as currently experienced among some persons in Nigeria. The truth is that many Nigerians are indeed using vitamin $C$ enriched plants and vegetables to manage COVID-19 in Nigeria. Subsequently, various universities and research institutions in Nigeria are seriously working on vaccines and herbal remedies for COVID-19 based on several combinations of the vitamin C enriched plants and vegetables.

\begin{tabular}{|c|c|c|c|c|c|}
\hline $\mathbf{S} / \mathbf{N}$ & Common Name & Botanical Name & Part in use & Region Used & Authors \\
\hline 1 & Apple & Malus domestica & Fruits & All & \\
\hline 2 & Avocado & Persea americana & Fruits & All & \\
\hline 3 & Banana & Musa acuminate & Fruits & All & \\
\hline 4 & Beetroot & Beta vulgaris & Bulbs Leaves & $\mathrm{NC}, \mathrm{NE}, \mathrm{NW}$ & \\
\hline 5 & Bitter kola & Garcinia kola & Seed & All & {$[14,16]$} \\
\hline 6 & Bitter leaf & Vernonia amygdalina & Leaves & SE, SS, SW, NC & {$[16]$} \\
\hline 7 & Black pepper & Piper nigrum & Fruits & SE, SS, SW, NC & [17] \\
\hline 8 & Carrot & Daucus carota & Rhizome & All & \\
\hline 9 & Cinnamon & Cinnamomum verum & Stem Back & All & {$[14]$} \\
\hline 10 & Coconut & Cocos nucifera & fruits & All & \\
\hline 11 & Cucumba & Cucumis sativus & Fruits & All & \\
\hline 12 & Fluted pumpkin & Telifarria occidentalis & Leaves & SE, SS, SW, NC & \\
\hline 13 & Garlic & Allium sativum & Bulb & All & [15-18] \\
\hline 14 & Giloy & Tinospora cordifolia & Leaves Stem & SE, SS, SW & {$[14]$} \\
\hline 15 & Ginger & Zingiber officinale. & Rhizomes & All & [14-19] \\
\hline 16 & Guava & Psidium guajava & Fruits & All & \\
\hline 17 & Holy basil & Ocimum sanctum & Leaves & SE, SS, SW, NC & [16] \\
\hline 18 & Honey & Apis cerana & & All & {$[14,16]$} \\
\hline 19 & Lemon grass & Cymbopogon citratus & Leaves & All & {$[16]$} \\
\hline 20 & Lettuce & Lactuca sativa & Leaves & & \\
\hline 21 & Lime & Citrus aurantifolia & Fruits & ALL & {$[12,14,16,18]$} \\
\hline 22 & Miango (Red) pepper & Peppers capsicum & Fruits & $\mathrm{NC}$ & \\
\hline 23 & Neem (Nimtree) & Azadirachta indica & Leaves Stem Back & ALL & {$[16]$} \\
\hline 24 & Negro (Guinea) pepper & Xilopia aethiopica & Fruits & SE, SS, SW, NC & {$[16,17]$} \\
\hline 25 & Nsukka(Yellow) pepper & Capsicum annuum & Fruits & SE & \\
\hline 26 & Onions & Allium cepa & Bulb & All & \\
\hline 27 & Orange & Citrus sinensis & Fruits & All & {$[12,16,18]$} \\
\hline 28 & Pawpaw & Carica papaya & Fruits Leaves & All & \\
\hline 29 & Pineapple & Ananas comosus & Fruits & All & \\
\hline 30 & Sage plants & Salvia officinalis $L$ & Stems Leaves Flowers & SE, SS, SW, NC & \\
\hline 31 & Saint leave & Ocimum basillicum & Leaves & All & \\
\hline 32 & Strawberry & Fragaria ananassa & Fruits & $\mathrm{NC}, \mathrm{NE}, \mathrm{NW}$ & \\
\hline 33 & Tomatoes & Solanum lycopersicum & Fruits & All & \\
\hline 34 & Turmeric & Curcuma longa & Rhizomes & All & {$[12,14,16,17]$} \\
\hline 35 & Uhio & Tetrapleura tetraptera & Flower Fruits & SE, SS, SW & \\
\hline 36 & Ukazi & Gnetum Africanum - & Leaves & SE, SS & \\
\hline 37 & Utazi & Gongronema latifolium & Leaves & SS, SE, SW & \\
\hline 38 & Uziza \{false cupep leaves) & Piper guineense & Leaves & SE, SS, SW & \\
\hline 39 & Water melon & Citrulus lanatus & Fruits & All & \\
\hline 40 & Yellow mombin (Hug plum) & Spondia mombi & Fruits leaves & All & \\
\hline
\end{tabular}

Table 1: A to Z Vitamin C enriched plants and vegetables used in Nigeria for COVID-19.

\section{References}

1. Nigeria Centre for Disease Control - NCDC (2021) Updates on COVID-19 (Coronavirus Disease 2019).

2. Calder PC, Carr AC, Gombart $\mathrm{AF}$ and Eggersdorfer $\mathrm{M}$. Optimal Nutritional Status for a Well-Functioning Immune System is an Important Factor to Protect against Viral Infections (2020) Nutr 12: 1181 .

https://doi.org/10.3390/nu12041181

3. Ohanube GAK and Obeta MU. COVID-19: Novel Opinion on Strategic Prophylaxis and Cure Using Vitamin C (Ascorbic Acid) (2020) Act Sci Nutr Health 4: 32-33.

https://doi.org/10.31080/asnh.2020.04.0697
4. Khaled $\mathrm{MB}$ and Benajiba $\mathrm{N}$. The role of nutrition in strengthening immune system against newly emerging viral diseases: case of SARS-CoV-2 (2020) North African J Food Nutr Res 4: 240-244. https://doi.org/10.5281/zenodo.3749406

5. Omer AFA. Against COVID-19: Herbal Theory (2020) Saudi J Biomed Res 5: 80-81. https://doi.org/10.36348/sjbr.2020.v05i05.002

6. WHO supports scientifically-proven traditional medicine.

7. Africa Centers for Disease Control and Prevention. Statement on herbal remedies and medicines for prevention and treatment of COVID-19. 
8. Vitamin and mineral requirements in human nutrition (2004) World Health Organization and Food and Agriculture Organization of the United Nations.

9. Choi SH. WHO Traditional Medicine Strategy and Activities "Standardization with Evidence-based Approaches" (2008) J Acupunct Meridian Stud 1: 153-154.

10. Akram M, Michael SO, Saeed M, Adetunji CO, Zahid R, et al. 5-Ethnopharmacological properties of Asian medicinal plants during conflict-related blockades (2021) Photochemistry the Military and Health 5: 53-68

https://doi.org/10.1016/B978-0-12-821556-2.00025-6

11. Ezekwesili-Ofili JO and Okaka ANC. Herbal Medicines in African Traditional Medicine (2019) Herbal Medicine. http://dx.doi.org/10.5772/intechopen.80348

12. Akindele AJ, Agunbiade FO, Sofidiya MO, Awodele O, Sowemimo A, et al. COVID-19 pandemic: a case for phytomedicines (2020) Nat Prod Commun 15: 1-9. https://doi.org/10.1177/1934578X20945086

13. Enani SM. Possible Prophylactic and Therapeutic Foods for Prevention and Management of COVID-19- An Updated Review (2020) Current Res Nutr and Food Sci 8: 682-689. https://doi.org/10.12944/CRNFSJ.8.3.02

14. Obeta MU, Ikeagwulonu RC, Ohanube GAK and Jwanse RI Some Igbo Indigenous Plants with Anti-COVID-19 Properties (2020) IntechOpen.

15. Akram M, Ugariogu SN, Sagheer MS, Saeed MM, Tahir IM, et al. The Potentials of Medicinal Plants in the Treatment of COVID-19 Patients: Review (2021) Int J Pharmacogn Chinese Med 5.
16. Oladele JO, Ajayi EI, Oyeleke OM, Oladele OT, Olowookere $\mathrm{BD}$, et al. A systematic review on COVID-19 pandemic with special emphasis on curative potentials of Nigeria based medicinal plants (2020) Heliyon. https://doi.org/10.1016/j.heliyon.2020.e04897

17. Onyeaghala AA, Onyeaghala EO, Babalola CP, Aina $\mathrm{OO}$ and Jelpe DD. Herbal supplement (Combi-5) in the management of COVID 19 individual with mild to moderate symptoms: a case report (2021) J Complement Integr Med. https://doi.org/10.1515/jcim-2020-0430

18. Dwivedi LD and Pandey SD. A Novel Synergistic Medicinal Composition for Treatment of COVID-19 (2020) European J Biomed and Pharmaceutical Sci 7: 662-668.

19. Obeta MU, Ohanube GAK, Ezeugwu EMO, Mantu EC, Etukudoh NS, et al. Using decoction of some vitamin C enriched plants for the management of COVID-19 in Jos, Nigeria: A case report (2021) J Current Biomed Rep 2

20. Ohanube GAK, Obeta MU, Ikeagwulonu RC and Jwanse IR. COVID-19: A Case Study of Using Vitamin C Enriched Plants and Ascorbic Acid as Cure (2020) American J Medical Case Reports 8: 435-437. https://doi.org/10.12691/ajmcr-8-11-16

21. Ohanube GAK, Obeta MU and Ikeagwulonu RC. Case reports in the use of vitamin $\mathrm{C}$ based regimen in prophylaxis and management of COVID-19 among Nigerians (2020) J Curr Biomed Rep 1: 77-80. 